\title{
Global News Communication Strategies
}

\author{
9.11. 2002 around the World ${ }^{1}$
}

\author{
Lisbeth Clausen
}

\begin{abstract}
“(..) since September 11 it has become obvious that the concept of the national public sphere has - again - changed. Given the global interconnectedness of media, the public sphere has become increasingly integrated into a global network society, with new sub-national and supra-national coordinates, and - in consequence - new players and alliances, such as al-Jazeera, the broadcasting station from Qatar. Given this new news infrastructure, conventional formats of "domestic" and "foreign" journalism have to be reviewed, in order to define the particular role and responsibility of journalism in a global public sphere." (Barbie Zelizer \& Stewart Allan, 2002: 21)
\end{abstract}

Since 9.11., the conditions for international news production have changed - again - but with what consequences? Do the global interconnectedness of media and the increasing integration of new players affect the production of global news and in what ways? And how do news producers working between the global and the local deal with the new formats of 'foreign' and 'domestic' news? The complexity of the new scenario and the consequences of technological development for globalization processes pose new challenges for national media institutions. National news producers choose their international footage from increasingly integrated networks of global and local news suppliers, and in doing so their role as mediators becomes one of consciously creating a national cultural identity in relation to other national identities. Communication strategies in the newsrooms thus become culturally 'reflexive' considerations (Harvard 2001: 10) about

Copenhagen Business School, Dalgas Have 15, DK-2000Frederiksberg,lc.ikl@cbs.dk how to present international political affairs, on the one hand, and meet national political agendas and audience demands for familiar perspectives, on the other. The complex relationship between the global and the local, or between 'foreign' and 'domestic' affairs, in national news mediation is apparent across cultures, as exemplified in the study of news output presented here. Visual coverage and political commentary are no longer 'either/or' but a mix of both. Following the first week after 9.11., the US media served as a co-orientation source for international coverage. Hence familiar local, domestic contexts were being used to integrate the global event in increasingly local discourses - in a process of 'regionalization' (Volkmer 2002: 239). A similar notion - namely that of 'proximity' as a professional news value - has been referred to in the classic studies of news production (See Tuchman 1991; Cottle 2001 for a review). Proximity in news values and narrative forms is becoming more prevalent in the fierce competition for viewer ratings (Hjarvard, 2001). The process of selecting particular elements and adapting global information to suit a local framework is referred to in this project as 'domestication'. The focus of discussion is the new challenges and strategies used by national news broadcasters after 9.11. to familiarize international news stories. It is concluded that the 'new global public sphere' in this perspective is more appropriately termed using the plural form as new global public spheres.

\section{The Culturally Integrative Character of National News Broadcasting}

While global news distribution is influenced by the increasing integration of global information networks, with new sub-national and supra-national coordinates, as mentioned above, there is also an in- 
creasing number of competing national and international channels offering news programmes. This, however, has not altered the fact that television news broadcasting remains a primary source of information about the world (Dahlgren, 1995). Television news, therefore, is an important source of information about international affairs and an important public forum of study, which reflects international political affairs. Studying the flagship news programmes offers insights into the socio-politically integrative character of national broadcasting, and makes the diverse interpretation of news information within different regional and national frameworks apparent. Accordingly, audiences view international news in terms of their national frames of reference (Jensen, 1999). The strategies of news producers differ not only in terms of the agendas of national broadcast media, but also in terms of the organizational and professional presentation practices of public service and commercial stations (Helland, 1993; Clausen 2003a).

\section{Global News Homogenization or Differentiation?}

The technological development and new constellations of information networks have also called attention to the fact that the ownership of news-providing organizations is in the hands of a few conglomerations. The global infrastructure of media organizations and the inter-connectedness between suppliers of news influence content and have resulted in a diffusion of homogenized news worldwide (Paterson, 1998; Boyd-Barrett, 1998). The standardization of working processes and the MacDonadization of news output caused by these supplier conglomerates (mainly Anglo-Saxon) are suited to Western political and economic interests. (Al-Jazeera has broken this Western news monopoly). The communication logic guiding these studies of international news agencies is that news footage is made available by the international agencies and national news institutions in this perspective function as gatekeepers who can select or reject incoming footage. The present study of 'global' news dissemination, such as the commemoration event of 9.11. 2002, exemplifies processes of both homogenization and diversification of news images. In other words, the main theme in the news reports is inspired by the same event and much footage is generated from the international news agencies and used by national news providers. However, it is found that public service as well as commercial broadcasters around the world make considerable national 'spins' on their primetime stories. International news producers still produce news from the point of view of domestic interests. Hence news producers, although still influenced by the agendas of the international agencies, set out to choose the most appropriate pictures, and more importantly they produce their own footage and feature stories with their own audiences in mind.

\section{The Global and the Local}

In order to explain the dialectic processes between global dissemination of news (standardization) and the local (differentiation), from the point of view of national news producers, the notions of 'universal' as well as 'particular' features (Robertson, 1992) are helpful. The universal characteristics of news communication refer to global formats and genre conventions, while the particular characteristics refer to socio-cultural themes, actors and communication strategies in national media institutions.

\section{The 'Foreign' - 'Domestic' Divide}

It may be argued that the 9.11. 2002 commemoration event is an American domestic event and wholly foreign in European, Asian and Arab newsrooms. It is defined here as a 'global' news story for three reasons: a) the event was reported in all countries studied, b) similar visual footage was transmitted across cultures, and c) its political scope has had an impact on nations worldwide. Furthermore, its emotional content has had an impact on TV audiences throughout the world. Most citizens were emotionally affected by the initial incident and the study shows how news producers capitalized on the shared knowledge and interest in this story by giving the commemoration event in 2002 high priority.

\section{'Domestication' Strategies}

The notion of 'domestication' is inspired by the research of Gurevitch et al. 1991. Based on their study of news production and audience reception in several European countries, Gurevitch et al. conclude that in order to be judged as newsworthy, an event has to be anchored 'in a narrative framework that is already familiar to and recognisable by newsmen as well as by audiences' (Gurevitch, Levy \& Roeh, 1991: 207). 'Domestication' thus refers to audience appeals and efforts to shape news into frames of reference and ways of perceiving international events that are similar for news producers and audiences in the same national culture. It is 
worth noting that while the notion of 'domestication' in the study of Gurevitch et al. serves as a counter-conceptualization to the notion of globalization, the present study views the process of 'domestication' as an inevitable part of the globalization process.

'Bringing information home' ('domestication') is thus ingrained in the professional strategies of news producers in their efforts to reframe and recontextualize news output to target their local audiences. While processes of 'domestication' have been studied in news production processes in one culture, namely the Japanese (Clausen 2003b), here strategies of 'domestication' are studied across cultures.

\section{The Role of Journalists and 'Good Journalism' in the News Public Sphere}

Much literature has been written about news criteria and journalistic values. I refer here to the classic newsroom studies. Before turning to the method and data, let me briefly introduce a popular version of what good journalism is assumed to be: "Stick to the facts. Don't make too many judgments. Leave opinions out of it. Separate your personal convictions form your professional duties. Remain neutral. Offer people good information; let them decide what it means. Treat both sides with respect; don't pick one over the other. Strive for the balanced view. Try to be as objective as possible, even though we are all human. Stay detached. Don't get sucked in by the emotions of the moment" (Rosen 2002:34). It is argued, and exemplified in the following, that journalistic strategies of 'factuality' and 'impartiality' are neither practiced in the US nor in any other country. All national broadcasters are found to be biased in favour of their own national political and organizational interests.

\section{Method and Data}

Tape-recorded news programmes from 6 countries covering the EU, the US, Asia and the Middle East are the basis of analysis (see display). The news programmes are flagship programmes and primetime news shows in their home countries. The US programmes are broadcast around suppertime, the Canadian programme is a special report later at night, the Irish and Danish programmes are broadcast early evening, while the five Japanese primetime programmes are broadcast late at night. The late-night Japanese programmes cater to the Japanese business people (salary men) who arrive home late in the evening. While the primetime news programmes in most countries last half an hour without commercials, the Japanese programmes last almost two hours interrupted by 1-2 minute commercial slots every seven minutes. The programme of the Japanese public station NHK 'only' lasts an hour. Unlike its commercial competitors, NHK does not include commercials. The Arab programme A1Jazeera is a late afternoon programme. Al-Jazeera is based in Qatar, but transmits its news programmes to all Middle Eastern countries and reaches most parts of Europe.

Although the American Fox TV, owned by the media conglomerate Murdoch News Corporation, is increasing in popularity and gaining viewer ratings, it was not included in the study. It should be noted that Fox TV is of much concern to US intellectuals because it is viewed as a mouthpiece for Bush Administration propaganda. The Danish national TV station DR was not included as originally planned because news workers were on strike and the news had been cancelled. A programme from China did not make it through customs, and the Canadian primetime programme was only partly broadcast because of technical difficulties due to stormy weather. The Canadian special news programme is analysed in its stead.

A research assistant and the author have translated the Japanese and Danish programmes into English during the coding process. A native Arabic speaker has translated the Al Jazeera programme while coding it. The coding categories include glo$\mathrm{bal} /$ national themes, US/national victims, staging of anchors, and the political perspective on Bush/Bin Laden. Patterns in the coded material are summarized below and accounted for systematically.

\section{US, EU, Asian and Arab Coverage of 9.11. 2002}

The one single visual theme that stood out in all broadcasts is the NY trade towers. The towers have in this respect become the visual icon of the 9.11 . event. Visuals of the towers were shown repeatedly in many forms and variations in all broadcasts. In the US, ABC's Peter Jennings was standing in front of the reconstructed towers: "This is as you can see a dramatic adaptation of the NY skyline and a representation of the lost towers" (Peter Jennings points to towers in the background). In Canada, the towers were shown in flames with people ready to jump. In Japan, broadcasters showed a number of private video clips of the falling towers. Screens in the studio background showed the planes crashing 


\begin{tabular}{|c|c|c|c|c|}
\hline Countries & Stations & Name of the News Programme & $\begin{array}{l}\text { Public Service or } \\
\text { Commercial Station }\end{array}$ & $\begin{array}{l}\text { Anchor's Name } \\
\text { (only newscasters) }\end{array}$ \\
\hline \multirow[t]{4}{*}{ US } & PBS & $\begin{array}{l}\text { The News Hour with Jim Lehrer } \\
\text { (6:00 PM - 6: } 30 \text { PM) }\end{array}$ & Public & Jim Lehrer \\
\hline & CBS & CBS Evening News (6:00 PM - 6:30 PM) & Private & Dan Rather \\
\hline & NBC & $\begin{array}{l}\text { NBC Nightly News with Tom Brokaw } \\
(5: 30 \text { PM - 6:00 PM) }\end{array}$ & Private & Tom Brokaw \\
\hline & $A B C$ & $\begin{array}{l}\text { World News Tonight with Peter Jennings } \\
\text { (5:30 PM - 6:00 PM) }\end{array}$ & Private & Peter Jennings \\
\hline Canada & $\mathrm{CBC}$ & $\begin{array}{l}\text { The National (10:00 PM -12:00 PM) } \\
\text { Special extended edition }\end{array}$ & $\begin{array}{l}\text { Public (money also } \\
\text { through commercials) } \\
\text { but financed mainly by } \\
\text { public funds) }\end{array}$ & Peter Mansbridge \\
\hline \multirow[t]{5}{*}{ Japan } & NHK & NHK News10 (10:00 PM-10:55 PM) & Public & $\begin{array}{l}\text { Miyuki Morita } \\
\text { Tamaki Imai }\end{array}$ \\
\hline & Asahi & News Station (9:54 PM-11:10 PM) & Private & $\begin{array}{l}\text { Mari Watanabe } \\
\text { Jun Hagitani }\end{array}$ \\
\hline & TBS & News23 (10:54 PM-12:50 PM) & Private & Tetsuya Chikushi \\
\hline & Fuji & FNN News Japan (11:00 PM - 0:40 PM) & Private & $\begin{array}{l}\text { Yuuko Andoo } \\
\text { Taroo Kimura } \\
\text { Sayaka Morimoto }\end{array}$ \\
\hline & NTV & Kyou no dekigoto (11:29 PM-12.03 AM) & Private & $\begin{array}{l}\text { Yumi Ida } \\
\text { Junko Toyoda }\end{array}$ \\
\hline Ireland & RTÉ & $\begin{array}{l}\text { Nine O'Clock News and Weather } \\
\text { (9:00 PM - 9:30 PM) }\end{array}$ & Public & Anne Doyle \\
\hline Denmark & TV2 & Nyhederne (7:00 PM - 7:30 PM) & $\begin{array}{l}\text { Semi public service/ } \\
\text { commercial }\end{array}$ & Caroline Boserup \\
\hline $\begin{array}{l}\text { Saudi Arabia } \\
\text { Qatar }\end{array}$ & Al-Jazeera ${ }^{2}$ & $\begin{array}{l}\text { News on the Half Hour } \\
\text { (afternoon news) }\end{array}$ & $\begin{array}{l}\text { Private /owned by } \\
\text { Allied Media Corp. }\end{array}$ & Khadija Bin Qanna \\
\hline
\end{tabular}

into the towers, while the news anchors introduced the story. Al-Jazeera showed detailed pictures of the constructions of the towers in an analysis of how they broke down.

The American media scholar Barbara Zelizer offers three reasons for the use of pictures that may together explain the almost excessive display of the towers in the reporting of the commemoration event: Photography is an integral part of journalism, it is a tool for easing post-traumatic dissonance, and finally it is a mobilizer of support for strategic action (Selizer, 2002: 66). A fourth reason may be added in relation to the present research, namely a strategic use of 'visual priming'. The repetitive use of dramatic visuals helped the broadcast stations to capitalize on the shared or idiosyncratic emotions of audiences in response to the visuals of the falling trade towers. The global event was thus made tangible through the repetitive use of visual expressions to which most people have some kind of emotional attachment.
The 9.11. NY commemoration event is found to be the point of departure in the news broadcast in the US, the EU, Asia and in the Middle East. With these events as the frame of reference, the stations proceeded to make their own domestic appeals.

\section{The Commemoration Event A Global Theme}

The takes on the 9.11. US commemoration event were reported from three locations. In chronological order, the events took place at the newly repaired Pentagon outside of Washington, at the field in the countryside of Pennsylvania at Shanksville where United Airlines Flight 93 crashed, and at Ground Zero in NY with a ceremony comprising two and a half hours of name-reading. Reportage(s) from these events formed the basis of the main story in most news reports in the countries studied.

The American broadcasters PBS, NBC, CBS and $\mathrm{ABC}$ transmitted extensively from the events and 
the news programmes revolved around this theme. The Canadian public service station CBC started its transmission similarly: "Dawn in NY on a day that would be difficult for the United Sates to get through. A day of commemoration and raw emotion starting at Ground Zero." (Canadian CBC).

"Lawrence Christopher Abel..." "Vincent Abody....". Excerpts from the two and a half-hour of reading of the 2801 victims' names were shown in most countries. The numbers of victim were 2801 in NY, 184 in Washington D.C., and 40 in Shanksville as noted by the American PBC and NBC, and the Japanese NHK and Fuji TV.

The name "Todd Beamer"... echoes in the US commercial stations $\mathrm{ABC}, \mathrm{NBC}$ and the Canadian public service CBC programmes. This bears witness to the use of the same pool pictures from the international agencies and news providers around the world. The name-reading and the speech excerpts continued as frequent instalments throughout most news programmes.

Excerpts from the speech by President Bush and Secretary of Defence Ronald Rumsfeld were also included in most programmes. The Japanese public station and the American PBS showed lengthy clips of the formal events and speeches. Only the Japanese TBS stood out with a different overall theme in its programme. The Japanese commercial station NTV followed the general theme, but showed pictures different from those of the remaining countries. Al-Jazeera did not show the name-reading sequences, but showed excerpts from Bush's speech.

Interestingly, the public service channels in all countries (the American PBS, the Japanese NHK and the Irish RTÉ) broadcasted the two minutes of silence in NY. This seemingly long 120 -second sequence was not broadcast by any private stations, which shows a difference in priority and broadcast style between the public service and the commercial stations. The Japanese commercial stations that send commercial slots are particularly careful with their time - and make a special effort to keep up the pace and excitement. The commercial station TBS stands out among its Japanese competitors in the way it produces not only info-tainment news but also in its 'docu-drama' approach.

The US commercial channels $\mathrm{ABC}, \mathrm{NBC}$ and the Japanese public service station NHK, among others, presented a kaleidoscope of commemoration ceremonies from around the world. These, however, were not followed by representations of political worldviews.

Based on the above, it is found that the 'global' element of the dissemination of news involves the common theme and the similar visual representations across countries.

\section{The Domestic 'Spin'.}

Although the commemoration event is the point of departure of the evening news programmes in most of the countries, the domestic angle in the news is prominent.

In the US programmes, coverage is geared to an American audience throughout. The event is presented as a domestic news event and seen from the perspective of the American people, military and political VIPs.

The foci of the US channels, however, differed thematically across the four stations. The most significant differences were: PBS broadcasted events at length. For instance, President Bush's speech on Ellis Island was televised in full. PBS let the cameras roll without much commentary. CBS stood out with its several-minute closing speech about 'American virtues' made by CBS anchor Dan Rather. Significant for the NBC programme was its description of the 'different ethics' of the countryside in relation to 9.11. In the NBC programme, ordinary American people were chosen to express rural ethics. Among others, a cowboy made a short comment saying, "I guess the code of the West is we kind of take care of ourselves". The people of the small town of Salina (Kansas) represented the laid back, easygoing ways of the West. Finally, ABC presented a feature on how thousands of people have visited the square. "They have come to find a way to deal with their grief." It was also stated that "This was the day when the American people went back to business as usual." The US stories thus differed in their feature stories and subthemes.

In an appeal to its national audiences, the public service Canadian station broadcasted a piece on the airport that received American planes and the townspeople who took care of the passengers. The US ambassador was invited to reiterate 'the Canadian importance in the rescue assistance'. The Japanese broadcasters also had clear domestic spins. Only the public service station NHK, which employed the PBS style of letting the cameras role at length, posed the question "what does this mean for the Americans?" NHK provided information-intensive answers to the question through several on-location reports. It is worth mentioning that NHK used this media opportunity to promote its High Definition format. All footage was essentially recorded with Japanese equipment in order to trans- 


\begin{tabular}{lll} 
Country & Station & Domestic (theme) 'spin' \\
\hline US & PBS & Bush's full speech \\
& CBS & American virtues \\
& NBC & Countryside 'ethics' \\
Canada & ABC & Bush and families \\
Japan & CBC & Canada's importance 9.11. \\
& NHK & High definition promotion \\
& Asahi & Japanese name reading. \\
& TBS & 9.11 and the Japanese \\
Ireland & Fuji & Japanese commemoration \\
Denmark & RTV & Japanese view on Iraq attack? \\
Qatar & TV2 & Irish commemoration \\
\hline
\end{tabular}

mit in this format (Interview with the NHK Washington D.C. Director Mr. Teshima, May $\left.4^{\text {th }}, 2003\right)$.

The Danish public service/commercial station and the Irish public service channel showed commemoration events in their own countries. The Arabian channel Al-Jazeera presented reports about Saudi Arabia and her relations to the US and was the only country to report about Iran's denunciation of a US invasion of Iraq.

In conclusion, the commemoration event in NY at Ground Zero framed the primetime news programmes in the countries studied. Audio-visual excerpts of this event were represented and incorporated into all news programmes, while domestic and institutional spins were incorporated into this thematic frame.

\section{Victim Stories about US Citizens}

Following the commemoration event at Ground Zero, the theme most prevalent was personal stories about victims and their families.

The stations in Ireland, Denmark and Saudi Arabia (Qatar) did not present personal US victim stories. Only the US and Japan presented such stories. The coverage of personal stories may be expected in the US. However, there was not an excessive amount for two possible reasons: 1) the name-reading itself was emotional for the American audience and 2) adding emotional victim stories would have seemed exaggerated. The reason for the Japanese massive coverage of US victims may be explained by the fierce competition between the five national broadcasters. Emotional victim stories rate highly among viewers. Japan is historically closely connected to the US through trade, politics, and military, and not least through its extensive media coverage of these themes. The psychological sense of closeness and the feeling 'proximity' is top of mind in the Japanese newsrooms (See Clausen 2003a) and seemingly has affected the choice of stories.

\section{Transmittance of Domestic Victim Stories}

The stories about countries' own national victims exemplify that not any victim story is newsworthy. Each nation commemorated its own, and nations that have no victims did not focus particularly upon the personal human stories behind the event. The value and priority of news greatly depend on the nationality of the victims, and based on these news values, a sense of hierarchy is reified in the national focus on countries' own victims.

The US public service and commercial channels did not mention or represent victim stories beyond those of Americans. Countries with victims of their own nationality broadcasted stories about them. These countries include Canada with 24 victims, Japan with 22 and Ireland with 5. The stations in Ireland, Denmark and Saudi Arabia (Qatar) did not present personal victim stories.

It is obvious that the tragic events of 9.11. deserve media coverage, because of their international political and emotional implications. However, coverage of victim stories as presented here raises the 


\begin{tabular}{llll} 
Country & Stations & US & 'Domestic' \\
\hline US & PBS & - & - \\
& CBS & US & - \\
NBC & US & Business: Corporate loss & - \\
Canada & ABC & - & Canadian (24 victims) \\
Japan & CBC & US & Corporate Japanese (22 victims) \\
& NHK & US & Japanese \\
& Asahi & - & Japanese \\
& TBS & US & \\
Ireland & Fuji & US & Irish (5 victims) \\
Denmark & RTÉ & - & - \\
Qatar & TV2 & - & - \\
\hline
\end{tabular}

question of cynicism in journalistic news values as regards the choice of stories of national victims over those of victims from other countries. It also raises the question of why the 9.11. victim stories were newsworthy even in 2002, a year after the event, when thousands of new deaths could be reported from around the world. Against this backdrop, the news value of 'proximity' and the careful calculation of the national hierarchical order of newsworthiness in human tragedy may be characterized as a 'universal' of the journalistic profession.

\section{Political Commentary World Views on Bush}

News commentators are national icons and have great power in creating public opinion across cultures. Their introductions, comments and interpretations greatly influence the perspective and angle on stories. Most anchors and newsreaders presenting this special commemoration event were powerful and wellestablished at their respective stations. ${ }^{3}$

The reporting and political commentary in the US has been criticized by media scholars and professionals alike, “(..) the US became a key component of the dominant script for reporting 'The War against Terrorism' - a label produced by the administration and accepted uncritically as the rubric for coverage of the US' military action in Afghanistan". (Karim 2002: 106). Although this frame may have been transmitted worldwide, the 'spin' on this framework was not univocal across cultures.
The US programmes differed slightly and varied in their degree of support for the Bush administration. The political commentary of the US public service station PBS was short and to the point in presenting the commemoration event without victim stories and on-location journalistic impressions. The three US commercial stations in this light made use of untold amounts of "God Bless America", "God loves America" rhetoric along with extensive use of American symbols: the flag, military effects, national buildings, the national anthem and general statements about the nature of the American people. However, while CBS included no critical views of the Bush administration, NBC showed critical features and comments about the Bush administration's policies, such as the sacrifice of freedom and minority rights for the sake of security. Of the big three, ABC was the most supportive of Bush. The US programmes were generally pro-Administration and the rhetoric was patriotic ${ }^{4}$.

In contrast to the US commentary, most comments made by anchors and correspondent in the Canadian public service station $\mathrm{CBC}$ were understated or indirect. The Canadian channel took up the issue of US patriotism and commented that "Patriotism has gone too far in the US" (Peter Mansfield, CBC). Pictures supported the statement. Several critical views were offered on the Bush Administration through voices expressing different sides of the story.

The Japanese stations, overall, represented a wide spectrum of political views on the Bush Administration. The public service station NHK was 
neutral in its presentation and political commentary with neither pro nor contra remarks. The commercial TV Asahi's anchors held a critical attitude. The Japanese commercial station TBS presented criticism of and scepticism towards the Bush Administration throughout the programme. Chikushi Tetsuya, who is known for his political involvement (Cooper Chen, 1997) and courage in speaking out on political issues, was the anchor. However the set up this evening was more dramatic than usual with written slogans, extensive visuals of bin Laden, music, dramatic effects and audience involvement. The programme was framed around the question of 'justice' seigi and presented the message that the US does not practice what it preaches. TBS differed from the remaining stations in its transmission style. The Japanese commercial station Fuji was less dramatic than the TBS programme, however anchors did direct critical comments at the US Administration. Both Fuji and TV Asahi criticized US politicians for being 'black and white' in their 'good vs. evil' political perspective on the world. The Japanese commercial station NTV was neutral in its descriptions of the commemoration event, but reported very critically against the US war in Afghanistan.

Compared to the heated political commentary of the anchors in the Japanese news, the Irish public service station RTÉ's anchor Anne Doyle seemed more neutral in her reports and political commentary. One of the foreign correspondents, however, emphasized strongly and thereby supported the view of many European countries that the US must go through the UN to declare War on Afghanistan.

The Danish public service/commercial station TV2 generally represented a pro-US attitude. The many patriotic visuals presented in the Canadian news were not shown in the Danish programme. Could this be for fear that such visuals would have been excessively patriotic for the Danish audiences? There are a few critical comments throughout the programme though. The Danish commentary was based more on the reporters' emotional experience at Ground Zero than on factual information. The Danish programme did not present many voices and was generally less information-intensive than were the Japanese programmes.

The commentary about Bush and the US administration reflected the official political stand of the participating countries. Only the Japanese stations stood out with a range of very different political views, from pro-US to highly critical.

\section{The Other Side of the Story References to the Middle East}

The 'other' side of the conflict - namely the perspective of the Arab world - was mainly covered by the non-US media.

The US public service station PBS did not refer to Middle Eastern political actors whatsoever. The three commercial stations, on the other hand, did make several references to the proclaimed US invasion of Iraq, which was the top item on the political agenda of the UN meeting in NY the following day. The US role as the world's political leader was clearly established in the US news reports. The commercial US stations presented the invasion as inevitable, while stations outside the US, including Canada and Denmark, merely referred to it. The Irish station appealed to the US to let the issue be decided within the framework of the United Nations, while Al-Jazeera was the only station to present reactions from Arab countries. The Canadian public service station $\mathrm{CBC}$ represented the Arab view through several interviews. Many of the Arab interviewees were intellectuals who voiced critical opinions on the Bush administration's foreign policy.

The Japanese stations again varied in their coverage of Arab views. The public service station NHK did not represent views from the Middle East. It was instead US-focused in its report ${ }^{5}$. The commercial Japanese station TV Asahi was generally critical of the US and its invasion of Afghanistan. The commercial station TBS was on the whole critical of the US administration. The commercial station TV Fuji, similar to TV Asahi above, attempted to come to terms with the phenomenon of terrorism. TV Fuji presented a historical account of Arab extremism. Fuji did not take sides in its coverage. The Japanese commercial station NTV presented what it referred to as the 'US wrongdoings in Afghanistan' and criticized the US for what it referred to as 'terrorist attacks'.

The Irish public service station RTÉ presented the Arab views through a Palestinian Imam shown in a mosque. The RTÉ, as noted above, emphasized the importance of UN agreement on an invasion of Iraq.

The Danish public service/commercial station TV2 presented a kaleidoscope of excerpts form the boldest of the statements against Bin Laden. The Danish presentation stood out in its use of dry humour concerning the Bush/Bin Laden relationship ${ }^{6}$. 
The Arab news provider Al Jazeera was the only channel to cover political reactions in the Middle East. Kuwait and Saudi Arabia (strong supporters of the US) were covered extensively concerning their relationship with the United States. Al Jazeera also broadcasted the Iran's warnings with respect to a US invasion in Iraq. Al Jazeera's motto is "The Opinion, and the Other Opinion Too". This motto was carried out in the news studied, which did cover both sides of the story. In its coverage of the event since the fall of the trade towers, the station has had its biases, according to Chief Newsroom Editor Ibrahim Helal. But these biases are mainly towards the "humanitarian" side of any question (New York Times, 2003). In light of this statement, the journalistic values of Al-Jazeera may be considered biased. However, in a comparative perspective, the station merely did what the other stations were found to do - 'domesticate' their stories.

The author of "Islamic Peril: Media and Global Violence" Karim H. Karim criticizes the US media for focusing on the incidents themselves rather than on their broader causes. "Instead of exploring how the American government's own activities abroad may have possibly laid the groundwork for the resentment leading to attacks against Americans, the media generally echoed the Bush administration's polarized narrative frame of good versus evil." (Karim 2002:106). As seen above, many of the Japanese news programmes did discuss the problems of this polarized framework, while Canada and Denmark were also 'guilty' of presenting their reports within the 'good versus evil' framework. AlJazeera in a sense turned this framework on its head.

While it is true that journalists and political commentators try their best to make sense of ongoing events and at the same time to adhere to professional standards, they cannot help being influenced by previous experience and knowledge. This, according to some scholars, has affected the world image of Arabs in a negative way. As noted by Karim H. Karim "Dominant world-views of society are critical in shaping the(..) cognitive structures with which we make sense of ongoing events. Even though the events of September 11 were extraordinary, the reporting - following the initial period of disorientation - was shaped by frames that had been in place to cover such issues as violence, terrorism and Islam." (Karim 2002:102). Karim further states that "Northern observers are generally oblivious to, or perhaps choose to ignore, the consequences of their constant, collective gaze upon the Muslim object - a gaze which, despite its omnipres- ence, serves to mystify rather than enlighten." (Karim 2002: 107, added emphasis). While it is true that, in some news programmes, the Arab viewpoint was conveyed in a 'mystifying' manner, the framing and amount of coverage of the Middle East differed across stations. Some US stations represented Arab people as simply "one of us Americans" in a way that did not cater to a stereotyped image of Arabs. The Japanese commercial stations and Al Jazeera, as exemplified in the following, presented lengthy reportage from Middle Eastern countries that varied in terms of presentation of an image of 'the Arab'.

In sum, as stated by US scholars: "News from nowhere was not possible after September $11^{\text {th }}$; and this had a disorienting effect." (Rosen: 34-35). 'News from nowhere' does not seem possible anywhere in the world. 9.11. 2002 reporting provides evidence that national news producers are double bound in their efforts to, on the one hand, make neutral, impartial, fair and detached reports about 'foreign' affairs and to, on the other, make stories digestible for national audiences.

\section{Conclusion: The 'Global Sphere' or 'Global Spheres'}

The article provides evidence that 'global' news such as 9.11. 2002 contributes to both processes of homogenization and processes of diversification of news images and texts worldwide. In other words, although the main themes of the news reports were inspired by the commemoration event in the US and much footage was generated by the agencies - public service as well as commercial broadcasters around the world made considerable national 'spins' on their primetime stories.

It is found that the production strategies in the transmission of the 9.11. commemoration event in broadcast institutions around the world were similar in the way they 'domesticated' news to suit their national audiences. The victim stories, for example, were not universal, but dependent on the national origin of the victims. In other words, countries with national victims reported on their own. The Japanese in particular made great efforts to cover personal stories of their own victims. In their efforts and the atmosphere of competition to find the most interesting stories, they also reported some US victim stories.

It was found that so-called 'global' news is largely domesticated in order to appeal to national audiences. Stories were framed, angled, geared and worded to suit the emotional and cognitive frame- 
work of audiences at home. The perspectives on stories and the political commentary were provided by powerful newscasters who have been employed by the stations for a decade or more and who in most cases have untainted professional and private records. Common to these news professionals is their strong personal credibility and aura of trustworthiness. Their role of superiority is maintained in the news performance and they assist in setting up political VIPs and private citizens through their commentary, interviews and interaction on air. It was evident in the staging and 'choreography' of the news presentations that the important personal/ professional 'social capital' of news professionals, and in particular the icon anchors, was an important factor in the mediation of political messages. This phenomenon was similar across boarders. Some anchors/newsreaders were factual in style and some were opinionated. This was not only dependent on the authority and style of the news anchors, but also on the presentation of other voices and representations of other sides of the story.

\section{Notes}

1. I would like to thank my research assistant Tim Hansen for his invaluable help in coding the programmes. I also extend my appreciation to my colleagues for video-recording the TV programmes: Keio University, Professor Ito Youichi; NHK Broadcasting Culture and Research Institute, Senior Researcher Hattori Hiroshi; University of Southern California, Assistant Professor Chris Paterson, Knud Munk, Maureen Power, Matt Brown, John Hansen and Imran Shah.

2. Since 9.11., Al Jazeera has been an important player on the media market for two reasons. First, it provides much material about the Middle East to the international agencies and national broadcasters around the world. Since the Sept. 11 attacks on the US, Al Jazeera has been an important international player both as provider of visuals from the Afghan invasion and an influential news provider in the Arab world. Second, it reaches an estimated 35 million viewers a day and therefore is an important mediator of events in the Arab world.

Al Jazeera has 60 correspondents stationed around the world. The Qatari emir, Sheik Hamad ibn Khalifa al Thani, founded the station in 1996 with a five-year deadline to support itself. The emir has suffered diplomatically for his steady backing of the station he still owns. In September, Saudi
The article exemplifies communication strategies in the production and dissemination of political discourse and shows that although events may have global implications, there is no such thing as 'global' news congruent in theme, content and meaning. The event in focus was mediated differently across cultures. The study thus provides empirical evidence on the culturally integrative character of national news broadcast institutions in terms of their strategies to both re-construct and maintain the national. However, if you turn the argument on its head, national news producers - in the process of 'domestication' of international events - are also (re)-constructing and maintaining the notion of the global.

In conclusion, the rupture resulting from the events of September 11 may present a long-term opportunity for turning towards more authentic coverage of the world, as called for by Zelitzer et al. (2002: 18). However, the 'global consciousness' of world citizens in the new public sphere is only provided a broader perspective and more balanced coverage if viewers are regularly provided glimpses into several of these channels across boarders.

Arabia withdrew its ambassador, upset by criticism of the station by the founder of the modern Saudi state, Ibn Saud. Kuwait and Jordan closed the Al Jazeera news bureaus in their capitals (New York Times, 2003).

3. Following the attacks on 9.11., the US anchors, Dan Rather, Peter Jennings (although he is Canadian), and Tom Brokaw were accused of being 'egotist leftists' for their interest in disclosing the 'why' of the incident. Shortly thereafter, US journalism was criticized as being 'personal' (Stuart Allan, 2002: 127) and 'patriotic': "Work as a journalist became a specific way of being a patriot: an American first, a professional after that." (Rosen 2002: 35). American television has turned into "a mood of patriotism rather than informing viewers of the complex sometimes harsh realities they need to know." (cited in Zelitzer et al. 2002: 13).

4. The coverage characterizes the criticism of US media scholars: "Members of the public making their way through the September 11 coverage could learn much from what reporters told them about the "who", "what," "where," "when" and "how" of the attacks. The matter of "why," however, remained elusive (Zelizer and Allan, 2002: 10).

5. In its diplomatic role as a government mouthpiece (Krauss 2003), NHK was cautious in its broadcasting and made no controversial political statements on behalf of the pro-American (later pro-invasion) 
Liberal government of Japan. Through its sources and representation of voices, NHK indirectly got its opinions across (Clausen, 2003a).

6. This supports previous research on Danish prime time news programmes (Hjarvard 1999) and findings from comparative studies of Danish and Japanese news (Clausen, 2003a).

\section{References}

Boyd-Barrett, Oliver (1998) Global News Agencies, in Boyd-Barett, Oliver \& Rantanen, Terry (eds.) The Globalization of News. London: Sage.

Clausen, Lisbeth (2003a) Global News Production. Copenhagen: CBS Press.

Clausen, Lisbeth (2003b) "Localising the Global". 'Domestication' Processes in the Production of International, News, Media Culture and Society. London: Sage Publications.

Cooper-Chen (1997) Mass Communication in Japan, Ames: Iowa State University Press.

Cottle, Simon. (2000a) New(s) Times. Towards a 'Second Wave' of News Ethnography, The European Journal of Communications Research 25 (1) P. 19-41.

Dahlgren, Peter (1995) Television and the Public Sphere - Citizenship, Democracy and the Media. Sage: London.

Daniszewski, John (2003) Al Jazeera Draws Flak From All Fronts, New York Times, January 5.

Graber, Dorris (1984/1990) Processing the News. How People Tame the Information Tide. New York: Longman.

Helland, K. (1993) Public Service and Commercial News: Contexts of Production, Genre Conventions and Textual Claims in Television. Bergen, Norway: University of Bergen (Report No. 18).

Hjarvard, Stig (1999) TV-nyheder i konkurrence. [Television news in Competition.] Copenhagen: Samfundslitteratur.
Hjarvard, Stig (2001) News in a Globalised Society. Göteborg: Nordicom

Ito Youichi (1998) The Pattern and Determinant Factors of International News. Paper presented to the IAMCR, Glasgow.

Jensen, Klaus Bruhn (ed.) (1998) News of the World: World Cultures Look at Television News. London: Routledge.

Karim, H. Karim (2002) Making Sense of the Islamic Peril, in Allan, Stuart \& Zelizer, Barbie (eds.) Journalism after September 11. London and New York: Routledge.

Krauss, Ellis S. (2000) Broadcasting Politics in Japan. NHK and Television News. Ithaca and London: Cornell University Press.

McLuhan, M. (1960) Understanding Media: The Extensions of Man, New York: McGraw-Hill.

Navaski, Victor (2000) Foreword in Allan, Stuart \& Zelizer, Barbie (eds.) Journalism after September 11. London and New York: Routledge

Paterson, Christopher (1998) Global Battlefields, in Boyd-Barett, Oliver \& Rantanen, Terhi (eds.) The Globalisation of News. London: Sage

Robertson, Roland (1992) Globalisation, Social Theory and Global Culture. London: Sage

Rosen, Jay (2002) September 11 in the Mind of American Journalism, in Allan, Stuart \& Zelizer, Barbie (eds). Journalism after September 11. London and New York: Routledge.

Tuchman, Gaye (1991) Qualitative Methods in the Study of News, in Bruhn Jensen, Klaus \& Jankowski, N.W.: A Handbook of Qualitative Methodologies For Mass Communication Research. (eds.) London: Routledge.

Volkmer, (1999) CNN News in the Global Sphere. A Study of CNN and its Impact on Global Communication. Bedfordshire: University of Luton Press.

Volkmer, Ingrid (2002) Journalism and Political Crises, in Stuart, Allan \& Zelizer, Barbie Journalism after September 11. London and New York: Routledge 